Discussion Paper No. 10-070

Size, Value and Liquidity.

Do They Really Matter on an Emerging Stock Market?

Judith Lischewski and Svitlana Voronkova

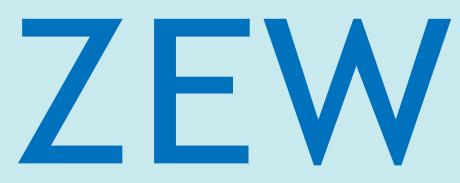

Zentrum für Europäische Wirtschaftsforschung $\mathrm{GmbH}$

Centre for European

Economic Research 


\title{
Discussion Paper No. 10-070 \\ Size, Value and Liquidity. Do They Really Matter on an Emerging Stock Market?
}

\author{
Judith Lischewski and Svitlana Voronkova
}

Download this ZEW Discussion Paper from our ftp server:

ftp://ftp.zew.de/pub/zew-docs/dp/dp10070.pdf

Die Discussion Papers dienen einer möglichst schnellen Verbreitung von neueren Forschungsarbeiten des ZEW. Die Beiträge liegen in alleiniger Verantwortung der Autoren und stellen nicht notwendigerweise die Meinung des ZEW dar.

Discussion Papers are intended to make results of ZEW research promptly available to other economists in order to encourage discussion and suggestions for revisions. The authors are solely responsible for the contents which do not necessarily represent the opinion of the ZEW. 


\section{Non-Technical Summary}

The paper provides new evidence on the factors that explain stock returns on the emerging markets. It focuses on the largest and most developed of the Central and Eastern European markets, the Polish stock market, which has been previously overlooked by the literature. In addition to the established factors, such as market, size and book-to-market value we investigate whether liquidity helps explaining Polish stock returns. The literature argues that liquidity should play a role on an emerging stock market where securities and investors are scarce and trading volumes are lower than on developed markets. The study is based on a hand-collected and carefully constructed dataset. In addition, our paper utilizes the largest array of liquidity measures considered in the literature to-date. In this way we ensure that our results are robust to multiple dimensions of liquidity. Our results support the hypothesis that the market, size, and book-to-market factors are important for explaining returns on the emerging Polish stock market. However, contrary to the expectations we do not find convincing evidence that liquidity is a priced factor. The results are robust across various liquidity measures and time periods.

\section{Das Wichtigste in Kürze}

Die Studie liefert empirische Evidenz hinsichtlich der Relevanz von Risikofaktoren, die Aktienrenditen in Schwellenländern erklären. Sie fokussiert auf den polnischen Aktienmarkt, der bisher in diesem Forschungsbereich nicht berücksichtigt wurde, obwohl größter und am weitesten entwickelter der Mittel- und Osteuropäischen Märkte. In der Literatur wird argumentiert, dass Liquidität in Schwellenländern aufgrund der im Vergleich zu entwickelten Märkten geringen Anzahl an Investoren und Wertpapieren, für die Bepreisung von Aktien relevant ist. Zusätzlich zu den bekannten Faktoren wie Gesamtmarkt, Unternehmensgröße und Buch-zu-Marktwert analysieren wir daher, inwiefern Liquidität bei der Preisbildung auf dem polnischen Aktienmarkt eine Rolle spielt. Die Untersuchung basiert auf einem eigenständig erhobenen und sorgfältig erstellten Datensatz. Um sicherzustellen, dass die empirischen Ergebnisse gegenüber verschiedenen Liquiditätsdimensionen robust sind, verwenden wir eine im Vergleich zu bisherigen Studien hohe Anzahl an Liquiditätsmaßen. Unsere Ergebnisse stützen die Hypothese, dass die Faktoren Gesamtmarkt, Unternehmensgröße und Buch-zu-Marktwert bei der Erklärung von Renditen auf dem sich entwickelnden Polnischen Aktienmarkt relevant sind. Im Gegensatz zu den Erwartungen bezüglich des Einflusses des Liquiditätsfaktors finden wir keinen überzeugenden Anhaltspunkt für dessen Bepreisung. Die Resultate sind hinsichtlich verschiedener Liquiditätsmaße und Zeitspannen robust. 


\title{
Size, Value and Liquidity.
}

\section{Do They Really Matter on an Emerging Stock Market? ${ }^{1}$}

\author{
Judith Lischewski $^{a *}$ and Svitlana Voronkova ${ }^{b * *}$ \\ ${ }^{a}$ Department of Economics, Westfälische Wilhelms-University Münster, Germany \\ ${ }^{b}$ Centre for European Economic Research (ZEW), Mannheim, Germany
}

August 2010

\begin{abstract}
The paper extends the evidence on the factors relevant for pricing stocks in emerging markets. While previous literature focused on Latin American and Asian developing markets, Central and Eastern European markets remain under-researched. By focusing on the Polish stock market, we aim to fill in a gap in the asset pricing literature and draw attention to these previously overlooked markets. In addition to analyzing the importance of the most prominent risk-factors such as market, size and book-to-market value, we investigate whether liquidity plays a role in pricing Polish stocks. To test this conjecture we use the largest array of liquidity measures that has been used in the literature to date. We take advantage of a hand-collected dataset covering the longest period studied so far in case of the this market. Our results support existing evidence for developed markets with regard to the market, size, and book-to-market factor. However, in contrast to studies on other emerging markets, we do not find convincing evidence in favour of the liquidity risk premium on the Polish stock market. This result is robust across various liquidity measures and time periods. Analyzing specific characteristics of the Polish market, we consider possible explanations behind this finding.
\end{abstract}

JEL-code: G10 G12

Keywords: Liquidity, Size Effect, Value Effect, Expected Stock Returns, Eastern Central European Stock Markets, Emerging Markets.

* Corresponding Author: Judith Lischewski, Department of Economics, Am Stadtgraben 9, D-48143 Münster, Germany, phone: +49 251 83-28200, judith.lischewski@wiwi.uni-muenster.de

** Svitlana Voronkova, Centre for European Economic Research (ZEW), L 7, 168161 Mannheim, Germany, phone: +49 621 1235-379, voronkova@zew.de

\footnotetext{
${ }^{1}$ Part of the paper was completed when Svitlana Voronkova was in the School of Business, Trinity College Dublin, Ireland. We are indebted to participants of the 6th Portuguese Finance Network conference, the "Xth Doctoral Meetings in International Trade and International Finance" organized by the network RIEF, the Conference "Heterogeneous Nations and Globalized Financial Markets: New Challenges for Central Banks", the 2nd International Conference "Economies of Central and Eastern Europe: Convergence, Opportunities and Challenges", and the reserach seminar of the Westfälische Wilhelms-University, especially to Martin Bohl, Crina Pingulescu, Christian Salm and Michael Schuppli for helpful comments and suggestions.
} 


\section{Introduction}

There is substantial empirical evidence that stock returns can be better explained by a combination of risk factors rather than by a single-factor model. Starting in the late seventies and early eighties a number of factors contributing to the explanation of the cross-section of average returns have been detected. These include size (Banz (1981), Reingaum (1981), Keim (1983), Fama and French (1992)), price-earnings ratio (Basu (1977), Reingaum (1981)) and momentum effect (Jagadeesh and Titman (1993), Brennan et al. (1998)). The seminal studies by Fama and French $(1992,1993,1998)$ show that a combination of size and bookto-market effect is better able to capture the cross-section of stock returns than the market beta alone. The results of these studies have not remained uncontested, with a number of papers suggesting explanations behind the size and book-to-market factors (Llewellen (1999); Ferson and Harvey (1999); Liew and Vassalou (2000)) and extensions to the original FamaFrench three-factor model. In particular, the seminal paper of Amihud and Mendelson (1986) paved the way to numerous studies suggesting that liquidity may be the relevant factor that explains stock returns after the three Fama-French factors have been accounted for. The rationale behind is that illiquidity can be measured as costs of immediate execution and an investor willing to transact at a favourable price faces a trade-off: he may either wait to transact at a favourable price or insist to execute a transaction immediately at a current bid or ask price (Amihud and Mendelson (1986)). Transaction costs therefore represent a cash outflow that reduces future returns. Additionally, Glosten and Milgrom (1985) and Brennan and Subrahmanyam (1996) note that a primary cause of illiquidity in financial markets is the adverse selection, which arises from the presence of informed traders. If a marginal investor is uninformed, he may demand higher rates of return when the adverse selection problem is more severe. A substantial body of literature exists that confirms the presence of a liquidity effect on the US stock market (Amihud and Mendelson (1986), Brennan and Subrahmanyam (1996), Haugen and Baker (1996), Chalmers and Kadlec (1998), Datar et al. (1998), Brennan et al. (1998), Jones (2002), Chordia et al. (2001), Amihud (2002), Liu (2006) and Garleanu $(2009))$.

Bekaert et al. (2007) point out that liquidity risk is particularly important for the less sophisticated markets where the number of both securities and investors is scarce. To date, the empirical studies analyzing the influence of the above mentioned risk-factors on stock returns have concentrated on the more developed markets, such as US, UK, Japan, and 
Germany (Fama and French (1992, 1993, 1998); Griffin (2002); Schrimpf et al. (2007); Bauer et al. (2008); Hyde and Sherif (2009)). The few papers considering emerging markets either omitted Central and Eastern European emerging markets altogether or included only very limited sets of data. In this paper we expand the evidence on the factors affecting average stock returns by examining the returns on an important yet previously unexplored emerging market, the Polish stock market.

The Polish stock market is the largest in terms of market capitalization and number of listed securities in Central and Eastern Europe (CEE) and can also be deemed the most sophisticated. It therefore provides sufficient data for conducting asset pricing tests. Additionally, the institutional characteristics of this market, such as presence of a large number of small firms as opposed to a large number of medium-size and large firms on developed markets provides an interesting backdrop for testing what has become an established model.

The present paper contributes to the literature in several ways. Firstly, Central and Eastern European markets have been certainly under-investigated by previous studies. This paper fills this gap by providing evidence on pricing of market, size, value and liquidity factors in the largest and most developed of the CEE markets, the Polish stock market. Up to our knowledge, ours is the first paper to formally investigate which risk factor(s) help(s) to explain Polish stock returns. Secondly, when we study the importance of liquidity, we address the issue pointed out by Subrahmanyam (2009) and Liu (2006) about the robustness of the results to different controls for risk. We therefore use the so far widest range of liquidity measures to confirm our findings with regard to liquidity and capture the multiple dimensions of this factor. Such an approach may also help to identify which aspects of liquidity may have more prominence for asset pricing. We use a hand-collected and carefully compiled dataset on Polish equities. This allows us to ensure that the dataset is representative of the entire stock market and free from selection and survivorship biases. Methodologically, we rely on a pooled cross-sectional time-series estimation with Newey-West standard errors. We apply the single-factor CAPM model and the three-factor Fama and French (1993) model both with and without the liquidity factor. Our findings will therefore provide additional evidence on the extent and significance of the size, and value premiums on international markets and in addition give an insight into the importance of the liquidity factor in an important emerging market.

Our findings indicate that market factor, size factor and value factor play an important 
role in explaining returns of the Polish stocks. However, despite the significance of these factors and the expected direction of their effect, they do not fully explain returns on the Polish stock market. Contrary to our expectations and to findings by earlier studies on other emerging markets, we do not find evidence that the liquidity factor helps to improve the explanatory power of the three-factor model. The latter result is robust across various measures of liquidity and different estimation time periods.

The structure of the paper is as follows. Section 2 reviews the literature on the risk factors in emerging stock markets. Section 3 describes the data used and the construction of the portfolio returns, liquidity measures and factor portfolio returns. Section 4 presents the methodology used in the paper. Section 5 describes the empirical findings. Finally, Section 6 offers a summary of the estimation results and, based on them, conclusions.

\section{Literature Review}

Several papers have investigated the factors explaining stock returns in emerging markets. Claessens and Dasgupta (1995) study the cross-section of stock returns in twenty emerging markets over the period 1986-1993. They find that in addition to the market beta, size and trading volume have significant explanatory power in a number of markets, albeit with an opposite influence to the one found for the developed markets. Namely, the sign for the size factor and liquidity factor is found to be positive, while the sign of the value factor is found to be negative. The authors suggest that the reverse size and liquidity effects could have been driven by larger capital raising possibilities available to large companies in these markets, due to higher interest of foreign investors in the large stocks, availability of domestic government-subsidized credit or lower-cost international financing. In addition, the authors find that dividend yield, price-earning ratios and exchange rates are important in case of some of the studied markets. It should be pointed out, however, that the sample used in this paper includes only 96 monthly observations and a low number of stocks per country. The number of stocks per country ranges from as low as 22 to 137 . Rouwenhorst (1999) studies a somewhat longer period, i.e. from 1982 to 1997. Contrary to Claessens and Dasgupta (1995) he finds that the stock returns in emerging markets can be explained by the same factors as the returns in the developed markets. Namely, he finds that small stocks outperform large stocks and value stocks outperform growth stocks. He does not find, 
however, that liquidity, as measured by stock turnover, affects average stock returns in the studied emerging markets. Interestingly, the author documents a turnover pattern in the stock portfolios: stocks with high beta, small market capitalization, high past medium-term return or high book-to-market value display higher turnover than stocks with low beta, large market capitalization, and poor past performance or low book-to-market ratio.

Fama and French (1998) investigate whether value premium exists in the markets outside of the US. In addition to thirteen developed markets, they also study returns from sixteen developing markets over the period 1987-1995. Due to a relatively short sample period and a low number of stocks for emerging markets, Fama and French do not conduct asset pricing tests for these markets, but instead base their inferences on the size of the return difference between high and low value stocks. They find that the average difference between annual returns on the high and low book-to-market portfolios for all countries is nearly $17 \%$ when countries are value-weighted and $14 \%$ when they are equally-weighted. Barry, Goldreyer, Lockwood and Rodriguez (2002) study the robustness of both the size and value effects in emerging markets. They investigate thirty-five emerging markets over the period 19852000 and confirm the earlier results of Rouwenhorst (1999) about the presence of the value effect. However, the size effect in their sample depends on the inclusion of the extreme size values and on the method applied to calculate the size. The size effect persists when size is defined relatively to the overall market average, but it vanishes when the absolute firm size is included. In contrast to Barry et al. (2002), Wang and Xu (2004) find that the book-tomarket factor does not play a role for explaining returns of the A-class shares on the Chinese stock market, at least during the period 1990-2002. They do find that size and free float help to improve the explanatory power of the market model. Finally, van der Hart, Slagter and van Dijk (2003) find evidence in favour of size and value effects in internationally diversified stock portfolios but weaker evidence of these effects for individual country portfolios.

However, with the exception of van der Hart et al. (2003) and Barry et al. (2002) none of the papers mentioned above include Central and Eastern European stock markets. And even in the latter two studies the time period of these data is less than eight years. Baring in mind the short sample period and low number of securities, it is doubtful that accurate inferences regarding the asset pricing factors can be made. Therefore the authors had to combine the stocks from all emerging markets to construct the size and value portfolios with a sufficiently large number of stocks. However, such an approach does not allow making 
inferences about factors that matter in case of a particular emerging market.

Another drawback of the papers mentioned above is that none of them except of Rouwenhorst (1999) and Claessens and Dasgupta (1995) has explicitly considered the role of liquidity in explaining emerging market stock returns. Since the seminal papers by Amihud and Mendelson (1986) and Brennan and Subrahmanyam (1996) a number of studies investigated the importance of liquidity as a risk factor for asset prices. At least two explanations in favour of an impact of liquidity on asset pricing exist. Brennan and Subrahmanyam (1996) note that a primary cause of illiquidity in financial markets is the adverse selection which arises from the presence of informed traders. They argue that liquidity effects of asymmetric information are most likely to be captured in the price impact of trade. The second explanation arises from the discounted cash flow model: transaction costs represent a cash outflow that reduces future returns (Amihud and Mendelson (1986)). Amihud (2002) argues that illiquidity helps to explain part of the "small firm effect". Since illiquidity affects small firm stocks more strongly, in times of dire liquidity there is a "flight to liquidity" that makes large stocks relatively more attractive. Small stocks are subjects to greater liquidity risks and should therefore offer higher illiquidity risk premium. Sadka (2006) finds that a liquidity factor helps to explain part of the momentum and post-earnings announcement drift anomalies. The studies on liquidity effects are mostly conducted using US stock returns. These include, but limited to: Haugen and Baker (1996), Chalmers and Kadlec (1998), Datar et al. (1998), Brennan et al. (1998), Jones (2002), Chordia et al. (2001), Amihud (2002), Liu (2006) and Garleanu (2009). Evidence on the pricing of liquidity risk in international markets is provided by Amihud et al. (1997) for Tel-Aviv Stock Exchange, Hu (1997) for Tokyo Stock Exchange, Marcelo and del Mar Miralles Quiros (2006) for Madrid stock Exchange and Chan and Faff (2005) for the Australian stock market.

Bekaert et al. (2007) point out that liquidity risk is particularly important for the less sophisticated markets where the number of both securities and investors is scarce. Bekaert et al. (2007) find that in Latin American and Southeast Asian emerging stock markets liquidity is a priced factor and its importance has not changed after the liberalization. The authors find that unexpected liquidity shocks are positively correlated with contemporaneous return shocks and are negatively correlated with the dividend yield. However, neither Bekaert et al. (2007) nor Rouwenhorst (1999) nor Claessens and Dasgupta (1995) include any Central European stock market in their sample. This is another gap that the present paper aims to 
fill.

\section{Data}

After the breakdown of the communist era trading on the WSE started in 1991 with five listed companies traded at one auction per week. The number of traded stocks continuously grew and in 1994 trading started to take place on a daily basis. Two years later a continuous trading platform was introduced, bearing a minimum trade size requirement. Only the most liquid stocks were gradually introduced into the continuous trading system, while they were still traded on the action system as well. The WSE counted 83 listed stocks at the end of 1996. With the launch of the Warsaw Stock Exchange Trading System (WARSET) in 2000 liquid stocks were taken out of the auction system, so that shares were traded either in the call auction or in the continuous trading system. The required minimum trade size in the continuous trading system was dropped. Due to the WARSET traders obtained a better opportunity to follow the order book and to transfer and execute orders faster. In addition, the trading sessions have been prolongued and the importance of the continuous trading system grew further. After the introduction of WARSET shares traded on the continuous trading system accounted for more than $98 \%$ of the total turnover (WSE FactBooks). Until 2009 the number of traded shares by month was continuously increasing. At the end of 2009 market capitalization of the Warsaw Stock Exchange amounted to almost EUR 100 billions (EUR 99.8 billions), while capitatization of Prague and Budapest stock exchanges amounted to only EUR 48.9 billions and EUR 20.1 billions respectively. At the same time 379 stocks were listed on the Warsaw stock exchange, while only 25 stocks were listed on Prague Stock Exchange and 46 stocks on Budapest Stock Exchange (sources: World Federation of Exchanges (www.world-exchanges.org), Warsaw Stock Exchange (www.gpw.pl), Prague Stock Exchange (www.pse.cz), European Central Bank (www.ecb.int)). The starting date of our sample is stipulated by the need to ensure that the average number of stocks in the subsequently-formed portfolios is larger than ten. A minimum of 64 observations per month in 1996 provide a solid basis for a reasonable sorting.

Our dataset consists of all domestic stocks traded on the WSE from January 1996 to March 2009. Daily data on prices, dividends, market capitalization and book value was collected from the daily bulletin published by the WSE, "Ceduła". Data on trading volume 
and turnover was sourced from the online stock exchange information portal GPW-InfoStrefa (www.gpwinfostrefa.pl). To adjust for stock splits and right issues we collected corresponding information from the Polish National Depositary for Securities (www.kdpw.com.pl). This unique hand-collected and carefully assembled dataset allows us to be the first to profoundly investigate asset pricing on the Polish stock market. The daily data is used to calculate different liquidity measures. The derived monthly dataset forms the basis for the asset pricing analysis.

Liquidity can be defined as the difficulty of converting cash into assets and assets into cash. It has several dimensions: immediacy, transaction costs and price impact. Liquidity is an illusive concept which allows no single measure. Therefore, a number of liquidity measures have been proposed, capturing diverse aspects of liquidity. These include measures on bidask spread (Amihud and Mendelson (1986)), turnover- and volume (Brennan et al. (1998)), price impact (Amihud (2002)) and zero return (Lesmond (2005); Bekaert et al. (2007)). To account for the various aspects of liquidity and to provide a robust analysis, we use the so far widest range of liquidity measures, which are described in more detail below.

Lesmond et al. (1999) propose two versions of zero return measures. They use the simple proportion of days with zero returns to proxy liquidity. This measure helps to overcome the problem of data availability associated with the calculation of transaction costs. They propose to estimate transaction costs by means of calculating the proportion of zero returns over a given period of time. Their rationale is that informed investors trade only when a trade is profitable after transaction costs have been accounted for. That is, if the value of the information does not exceed the costs of trading, then the informed investor will not trade, causing a zero return. A security with high transaction costs will have less frequent price movements and more zero returns than a security with low transaction costs. This approach is rooted in the adverse selection framework of Glosten and Milgrom (1985) and Kyle (1985). We refer to the zero return measure of Lesmond et al. (1999) with LIQ_Zero.

Stocks featuring high transaction costs are also likely to have zero returns, even on positive-volume-days, since they most likely have no information-relevation. Therefore, Lesmond et al. (1999) propose an alternative zero return measure, which takes only those trading days with zero returns into account, which have a positive volume at the same time. This measure is also used in Bekaert et al. (2007). Subsequently, LIQ_Zero2 refers to this measure. 
Turnover is one of the frequently used measures of liquidity (Lesmond (2005); Rouwenhorst (1999); Datar et al. (1998); Haugen and Baker (1996)). Constantinides (1986) proves theoretically that investors react to higher trading costs by reducing the frequency and volume of their trades, which results in lower turnover. Thus, turnover allows us to capture average trading costs over the cross-section of trade sizes whereas quoted bid-ask spread measures the cost of a round-trip small size transaction. Amihud and Mendelson (1986) find that turnover is negatively related to illiquidity costs. Atkins and Dyl (1997) find that there is a negative relationship between the reciprocal of turnover (measuring holding period) and bid-ask spread. Cross-sectionally, stock returns are decreasing in stock turnover, which is consistent with a negative relationship between liquidity and expected return (Haugen and Baker (1996); Datar et al. (1998); Rouwenhorst (1999); Chordia et al. (2001)). We use the measure by Lesmond (2005) in order to capture the turnover-dimension of liquidity. We define monthly turnover measure as a ratio of daily trading volume to the number of shares outstanding on a given day, summed over the trading days in a given month ${ }^{1}$. We denote this measure as LIQ_Les.

Another liquidity measure, referring to the number of zero daily volumes in the prior $x$ months and to turnover at the same time, is suggested by Liu (2006). In addition, the measure adjusts for a varying number of trading months across months, which provides a solid comparability over time. Since the Liu measure (denoted as LIQ_Liu below) is based on trading volume data of the prior $x$ months, the sample size will be reduced depending on $x$. Since we are facing an emerging market dataset, we are restricted in this respect. Thus, we decided to calculate the LIQ_Liu for 6 rather than 12 months.

Amihud (2002) develops an illiquidity ratio which is defined as the ratio of absolute return to volume. The intuition for this measure is that liquid securities can accommodate large trading volumes with small price concessions. Below, we name this measure LIQ_Amh. Since average liquidity varies considerably over the years, LIQ_Amh is replaced in the estimation of the cross-section model by its mean-adjusted value (LIQ_AmhMA).

Since the Amihud ratio often exhibits extreme values, we also use a rescaled version suggested by Hasbrouck (2005), which is defined as the average of the square root of daily ratios, subsequently LIQ_ AmhSqr.

\footnotetext{
${ }^{1}$ Originally, the measure by Lesmond measures liquidity, whereas all other measures presented here measure the degree of illiquidity. In order to make the measure my Lesmond comparable to the other, we transformed it into an illiquidity measure.
} 
An alternative to account for extreme values of the Amihud measure is proposed by Cooper et al. (1985). They transform the daily values of the measure before averaging by calculating a logarithm. We refer to this measure by LIQ_AmhLog.

Roll (1984) suggests to use the effective spread estimator in order to measure liquidity. We compute the effective spread as $2 \sqrt{-\operatorname{cov} \Delta p_{t}, \Delta p_{t-1}}$, where $\Delta p_{t}$ and $\Delta p_{t-1}$ denote the first difference in log opening prices on day $t$ and $t-1$ respectively. In the following, the Roll (1984) measure is indicated by LIQ_Roll.

In literature, a modified version of LIQ_Roll is used, which takes into account that data might feature positive covariances. In cases when the covariance is positive the measure is defined as zero. We refer to this alternative measure as LIQ_Roll2. Table 1 gives an insight into the descriptive statistics of the calculated illiquidity measures ${ }^{2}$.

Table 1 about here

In order to examine whether size, book-to-market or liquidity effects are present on the Polish stock market we construct the size (SMB) and book-to-market (HML) factors along the lines of Fama and French $(1992,1993)$ as well as an additional liquidity factor. We form three portfolios on book-to-market ratio and two on size. The decision to form more bookto-market than size portfolios is stipulated by the evidence from Fama and French (1992) about a stronger role of the book-to-market factor in average stock returns.

In June of each year $t$ we sort the stocks according to size and book-to-market equity. The size sort relies on market equity measured at the end of June. The book-to-market sorting is based on market values of December of the previous year and the book values of the previous fiscal years ending. In Poland the corresponding book values are published by March of year $t^{3}$. Following Fama and French (1993), companies with a negative book value are excluded from the sample. The size portfolios are split into small $(\mathrm{S})$ and big (B) according to the median market value. We sort stocks into the three book-to-market portfolios according to the 3rd and 6th deciles of the ranked book-to-market values: low (L), medium (M) and high $(\mathrm{H})$. From the intersection of the relevant size and book-to-market deciles we construct

\footnotetext{
${ }^{2}$ We apply the augmented Dickey-Fuller and the Phillips-Perron unit root tests. Both tests reject the null hypothesis of unit root in the majority of cases. The results are not reported but available upon request.

${ }^{3}$ In less than $1 \%$ of cases we do not have access to the book values of the fiscal year ending in March. In those cases we use the values published in December of the fiscal year. Those values most likely refer to the book values of September of the previous year.
} 
six portfolios: S/L, S/M, S/H, B/L, B/M, B/H. We then calculate monthly value-weighted returns on the six portfolios for the period from July of year t to June of year $t+1$. Each year the six portfolios are re-formed again based on the new values of the market and book equity.

In order to investigate possible liquidity-effects we use illiquidity-ratios to portion the stocks into portfolios containing illiquid (I) and very liquid (V) stocks. Low values of the illiquidity measures indicate high liquidity, whereas high values of the measures indicate high illiquidity. We sort the stocks into the portfolios according to the average of each of the previously presented illiquidity measures across all stocks in a given year. The SMB (small minus big) factor, which mimics the risk factor in returns related to size, is calculated as the difference between the averages of the monthly returns on the three small $(\mathrm{S} / \mathrm{L}, \mathrm{S} / \mathrm{M}, \mathrm{S} / \mathrm{H})$ and the three big $(\mathrm{B} / \mathrm{L}, \mathrm{B} / \mathrm{M}, \mathrm{B} / \mathrm{H})$ size portfolios. The returns on the HML (high minus low) risk factor are correspondingly the difference between the simple average of the monthly returns on the two high-book-to-market $(\mathrm{S} / \mathrm{H}, \mathrm{B} / \mathrm{H})$ and the two low-book-to-market $(\mathrm{S} / \mathrm{L}$, B/L) portfolios. The IMV (illiquid minus very liquid) factor, mimicking the risk factor in returns in relation to liquidity, is the difference between the simple average of the monthly returns on the difference of illiquid (I/L/S, I/M/S, I/H/S, I/L/B, I/M/B, I/H/B) and very liquid stocks (V/L/S, V/M/S, V/H/S, V/L/B, V/M/B, V/H/B).

The proxy for the market factor is the excess market return $r_{m t}=R_{m t}-R_{f t}$. The WSE main market index WIG serves as a proxy for market portfolio, and the three-month Treasury bill rate is used as risk-free rate ${ }^{4}$. The data on WIG and on Treasury bill rate were collected from Datastream Thomson Reuters and Global Financial Data (www.globalfinancialdata.com) respectively.

Panel A of Table 2 presents selected descriptive statistics of the three Fama-French factor portfolio returns and on the liquidity factor portfolio returns, which have been formed according to the ten liquidity measures described earlier in this section. The distribution of the monthly market excess return has a negative mean return of -0.0055 and is negatively skewed. This may be explained by the fact that in a number of years the Polish stock market has shown negative and sometimes very large negative returns. The main stock exchange index, WIG had returns of $-12.80 \%$ in $1998,-21.99 \%$ in 2001 and $-51.07 \%$ in 2008

\footnotetext{
${ }^{4}$ We use the three-month Treasury bill rate as opposed to the one-month rate due to a large number of missing values in the series of one-month Treasury bill rates.
} 
(www.gpw.pl/zrodla/informacje_gieldowe/statystyki/Gpwspl.html). The standard deviation confirms the high volatility in the market excess returns. The market return distribution has excess kurtosis of about 5.5.

The statistics presented in Panel A of Table 2 confirm the presence of the size (SMB) and value (HML) premiums on the Polish stock market. The returns on the SMB and HML portfolios are both positive, with the value premium of $1.24 \%$ being somewhat higher than the size premium of $1.06 \%$. Similar results have been reported by Rouwenhorst (1999) for other emerging markets. This suggests that those risk premiums on emerging markets are similar to the ones documented for the developed markets (Fama and French (1993)). When we turn to the liquidity risk premiums, we observe that with the exception of two liquidity measures (zero returns measure (LIQ_Zero) and turnover-based measure (LIQ_Les)) the liquidity risk premiums are also positive, although in the majority of cases they are smaller than the magnitude of either size or value risk premiums. Panel B of Table 2 shows the correlation coefficients among the risk factors. With all but two correlation coefficients being well below 0.5 , we do not detect any overly high values of the correlation coefficients that may give rise to concerns about a multicollinearity problem.

Table 2 about here

Table 3 presents mean returns for the six size and book-to-market portfolios. The table shows that the small stocks outperform large stocks for all the three value categories. In addition, the descriptive statistics show that value stocks (stocks with high book-to-market values) outperform growth stocks (stocks with low book-to-market values). Average returns on Polish stocks were highest in the small value category $(\mathrm{S} / \mathrm{H})$ and lowest in the large growth category $(\mathrm{B} / \mathrm{L})$. This finding is in line with the one reported in Barry et al. (2002) for other emerging markets.

Table 3 about here

\section{Methodology}

In order to investigate the role of the diverse factors on asset pricing on the Polish market we employ four alternative pricing models and pursue a stepwise approach. The estimations can be partitioned in two main sections. We start analyzing the effect of the Fama-French 
factors on asset pricing. We sort the data according to size and book-to-market values into six portfolios and estimate the standard-CAPM:

$r_{j t}=\alpha_{j}+\beta_{j m} r_{m t}+\epsilon_{j t}$.

Thereafter we extend the model by the SMB and HML factors:

$r_{j t}=\alpha_{j}+\beta_{j m} r_{m t}+\beta_{j s m b} S M B_{t}+\beta_{j h m l} H M L_{t}+\eta_{j t}$.

This allows us to investigate whether size and book-to-market value are priced factors on the emerging Polish stock market. In order to analyze the influence of liquidity on asset pricing we sort the stocks into five liquidity-portfolios and estimate models (1) and (2) again for each of the portfolios. Following, both models are extended by the IMV-factor:

$r_{j t}=\alpha_{j}+\beta_{j m} r_{m t}+\beta_{j i m v} I M V_{t}+u_{j t}(3)$

$r_{j t}=\alpha_{j}+\beta_{j m} r_{m t}+\beta_{j s m b} S M B_{t}+\beta_{j h m l} H M L_{t}+\beta_{j i m v} I M V_{t}+\nu_{j t}$.

Where $r_{j t}$ is the excess return on portfolio $j, r_{m t}$ is the excess market return, $S M B_{t}$ is the mimicking portfolio for the size factor, $H M L_{t}$ is the mimicking portfolio for the book-tomarket factor, $I M V_{t}$ is the mimicking portfolio for the illiquidity factor, $\alpha_{j}$ is the intercept of portfolio $j$ and $\beta_{j m}, \beta_{j s m b}, \beta_{j h m l}, \beta_{j i m v}$ are the sensitivities to the risk factors. We estimate the models using the pooled cross-section time-series OLS estimator with Newey-West standard errors with 6 lags to account for heteroskedasticity and autocorrelation in the returns.

The number of stocks traded on the WSE is substantially smaller than that on developed markets. To ensure that the number of stocks in each portfolio $j$ is sufficiently large (i.e. not less than ten) in any given month, we construct a smaller number of portfolios than the conventional twenty-five or sixteen adopted in the studies of expected returns on developed stock markets. We apply difference in mean tests in order to analyze whether the magnitudes of the alphas differ between the portfolio containing very liquid and illiquid stocks, respectively. Implementing the Gibbons et al. (1989) test (GRS-test) enables us to analyse whether the pricing errors of the liquidity portfolios are jointly equal to zero.

\section{$5 \quad$ Empirical Findings}

We analyze the standard CAPM and the Fama-French three-factor model within a timeseries context for each of the six combined size and book-to-market portfolios. The objective of this approach is to investigate the role of the different risk factors on asset pricing on the Polish stock market. Table 4 reports the estimation results across the six portfolios and the 
two alternative risk-specifications represented by the CAPM and the Fama-French models. The results for the standard CAPM indicate that the risk-adjusted average returns, i.e. the intercept $\alpha_{j}$ of the regressions, are significantly different from zero for each of the analyzed portfolios. The majority of intercepts are significantly positive, suggesting a positive riskpremium for the stocks of the respective portfolios. Only the portfolio containing stocks with a high market value and a low book-to-market value $(\mathrm{B} / \mathrm{L})$ shows a significantly negative alpha. A comparison of the estimated alphas suggests that size and book-to-market factors influence the risk-adjusted average return. The coefficients' magnitudes increase in book-tomarket value and decrease in size. Thus, the results suggest that stocks featuring a higher book-to-market value are characterized by higher risk-premia, and big stocks typically have a lower risk-premium than small stocks. The estimated betas of the standard CAPM are all positive and significantly different from zero. Market betas are higher for big stocks, except in case of the high book-to-market stocks.

In oder to verify whether size and book-to-market are influencing the risk-premia on the Polish market we estimate Fama-French models for the above portfolios. A decrease in the magnitudes of the $\alpha_{j}$ in comparison to the intercepts of the standard CAPM indicates an existing influence. The right-hand-side of Table 4 reports the Newey-West estimation results for the Fama-French model. With the exception of the portfolio B/L, for which we found a significantly negative alpha in the standard CAPM, the magnitudes of the alphacoefficients of the Fama-French models are indeed lower than those of the standard CAPM. The increase of the alpha coefficient in book-to-market and the decrease in size is only present if one abstracts away from the portfolios with medium book-to-market value. Thus, including the size and book-to-market factors in the model reduces the strength of the relation between the intercepts of the portfolios in terms of size and book-to-market. This indicates that the corresponding factors do influence stock pricing in Poland. Therefore our results are in line with the findings of Rouwenhorst (1999) with regard to the importance and the expected signs of the size and book-to-market effects for stock returns in the emerging markets. However, it should be pointed out that Rouwenhorst (1999) did not include Central and Eastern European markets in his sample. The results with respect to value premium on emerging markets are in line with those of Fama and French (1998) and Barry et al. (2002). The beta of the Fama-French model is positive and significant, as it was the case in the standard CAPM. The estimated coefficients of the additional factors are significant for each 
portfolio. However, the alphas are still significantly different from zero. Thus, the results of the Fama-French model suggest that there must be another factor which influences the risk-adjusted average return on the Polish market.

Table 4 about here

As the literature review in Section 2 showed, liquidity may play a role as a priced factor. In order to analyze whether liquidity is the risk factor explaining the remaining non-explained risk-adjusted average return, we sort the stocks into five illiquidity portfolios ${ }^{5}$. The portfolio characterized by the lowest illiquidity value, referred to as P1, consists of the most liquid stocks, whereas the portfolio characterized by the highest illiquidity value, referred to as P5, consists of the most illiquid stocks. The portfolios are sorted according to ten different liquidity measures, enabling us to observe distinctions in the results regarding the chosen measure. We estimate the standard CAPM, the Fama-French model and both risk-specifications augmented by the liquidity factor IMV for each of the five portfolios sorted according to each of the ten liquidity measures. Table 5 gives an overview of the estimated alphas for the different risk-specifications and across the illiquidity portfolios, where P1 indicates the portfolio containing very liquid stocks, and P5 indicates the the portfolio with stocks featuring high illiquidity. The estimated alphas of the standard CAPM model are not significantly different from zero for the vast majority of portfolios. In case of the Fama-French model, 30\% of portfolios show significant alphas. A comparison of the estimation results in panel A and B with those of the corresponding liquidity-augmented models in panels $\mathrm{C}$ and D reveals a similar structure of the results. The addition of the liquidity factor does not have an influence on the estimation results. The number of significant intercepts does not decrease significantly after adding the liquidity factor. A comparison with estimation results in table 4 shows that the factor according to which the portfolios are sorted significantly influences the estimation results. Sorting according to book-to-market and size leads to significant alphas without exception, whereas sorting according to liquidity reduces the number of significant intercepts drastically. This applies especially for the CAPM, for which we find only three out of 50 alphas being significant when stocks are sorted according to liquidity.

\footnotetext{
${ }^{5}$ Due to a low variability in the liquidity measures LIQ_ZeroA and LIQ_Roll2, the data could not be sorted into five portfolios for some periods. Sorting the data into three portfolios solves this problem and serves as a robustness-check. We find that the major results are not influenced by the number of portfolios. The estimation results for three portfolios are available upon request.
} 
In order to test whether the estimated intercepts of the regressions for liquid and illiquid stocks differ in magnitude, we perform difference-in-mean tests. Finding that portfolio P5 has a statistically significantly higher alpha than portfolio P1 should indicate in favour of the liquidity premium on the Polish stock market, unexplained by market factor, size and book-to-market factors (Pastor and Stambaugh (2003), Marcelo and del Mar Miralles Quiros (2006)). The results show that the Null of equal coefficients may not be rejected for all four estimated models for the vast majority of illiquidity measures. In addition, we apply the test suggested by Gibbons et al. (1989) (GRS-test) in order to analyze whether the intercepts of the portfolios are jointly zero. Supporting our previous findings, the GRS-test results differ, depending on whether CAPM or FF-based models are observed. The Null is rejected for the majority of liquidity-measures for the Fama-French based models, whereas only the sorting according to zero-return measures leads to a rejection of the Null when CAPM models are observed.

It should be pointed out that the majority of the earlier reviewed studies use a single measure of liquidity. Cooper et al. (1985), Khan and Baker (1993), Amihud et al. (1997), Acharya and Pedersen (2005), Marcelo and del Mar Miralles Quiros (2006) and Kamara et al. (2008) use the Amivest measure of liquidity or it's inverse, the so-called Amihud measure; Haugen and Baker (1996), Datar et al. (1998) and Rouwenhorst (1999) use turnover; Amihud and Mendelson (1986), Eleswarapu and Reinganum (1993), Jacoby et al. (2000), and Chordia et al. (2000) use versions of a bid-ask spread measure. Only a handful of studies use several measures of liquidity (Atkins and Dyl (1997), Chordia et al. (2002)). This is a drawback, which Liu (2006) and Subrahmanyam (2009) has been calling to address. Our results demonstrate that it is important to rely on diverse measures of liquidity, since relying on a single measure may bias the results towards conclusions which might not be supported by other liquidity measures. This should especially be kept in mind, since liquidity is an illusive concept and its measurement is a challenging task.

The estimation results show that the illiquidity factor does not influence the risk-adjusted average return on the Polish market. Therefore, we conclude that liquidity is not a priced factor on the Polish market ${ }^{6}$. The significantly positive risk-adjusted average returns in the Fama-French three factor model must therefore be due to another risk factor, giving room

\footnotetext{
${ }^{6}$ We estimated the models for the following subsamples: 1996-2001 and 2002-2008 and we find that the results are robust.
} 
for further research.

Table 5 about here

As pointed out above, liquidity is expected to be particularly important on emerging markets. Surprisingly, this does not prove true for stocks traded on the Polish exchange. We are therefore interested in finding the reasons behind this result. One reason behind the lack of liquidity effect may potentially be rooted in the specific structure of the Polish stock market. In a small market, where larger stocks are owned by strategic or large institutional investors, only smaller securities remain available for trading. In this case the free float available is low for both larger and smaller stocks. As a result, the variability in liquidity among stocks stays low which results in the lack of liquidity effect. Based on these considerations, we would expect a weak link between size and liquidity. Our conjecture is supported by very low correlation coefficients between size and the liquidity measures. Besides, we find that the correlation coefficients are mainly negative, indicating a tendency toward a negative relation between size and illiquidity. This result indicates that the size factor, is not, however, responsible for the lack of liquidity effect ${ }^{7}$.

A lack of a liquidity effect may also be related to growing market-side liquidity. Increasing wealth and savings may result in an increasing participation in the stock market by the population. This may affect the extent of engaging in security investment and ultimately stocks' liquidity. However, gross saving rate in Poland has declined by 7.6 percentage points from 1997 to 2008 and stood at 6.5\% in 2008. This is well below EU-27 average of 11\% (http://epp.eurostat.ec.europa.eu/). Given the declining and relatively low saving rate in Poland during our sample period, we do not think this can explain the lack of liquidity effect we find in our sample.

In terms of model performance it is worth pointing out that the lowest incidence of significant unexplained excess returns as measured by alphas is documented in case of singlefactor and liquidity-augmented CAPM. The finding of superior performance of CAPM is not unique to this paper. For example, Marcelo and del Mar Miralles Quiros (2006) find that liquidity-augmented CAPM performs the best in case of the Spanish stock market. Schrimpf et al. (2007) also find that a version of conditional CAPM performs at least as well

\footnotetext{
${ }^{7}$ We calculated correlation coefficients for the whole sample, as well as for the subsamples 1996-2001 and 2002-2008 support our findings. Estimation results are not reported, but available upon request. In majority of cases correlation coefficient between size and liquidity measures did not exceed $|0.1|$.
} 
as conditional Fama-French model and even outperforms the latter in case of some of the goodness-of-fit metrics.

\section{Concluding Remarks}

The empirical evidence of previous literature suggests that a number of factors may help to explain the pattern of asset returns. This paper extends this evidence by studying the return patterns of the largest and the most developed stock market in the Central and Eastern Europe. Despite the size and significance of the Polish stock market in the region, up to our knowledge, there have been no studies into risk factors affecting its stock returns. The present paper investigates whether the factors that are found to be important for the developed and other emerging markets also play a role for asset pricing in this market. In particular, we investigate the relevance of the market, size, book-to-market and liquidity factors. While the first three factors have been well-established in the empirical finance literature, the liquidity as a risk factor has been somewhat overlooked by the previous research on emerging markets. This may potentially have important implications for making accurate inferences with regard to asset pricing as liquidity is deemed to be particularly important in the context of emerging markets where the number of securities, number of traders and efficiency of trading mechanisms is likely to be lower than in the developed markets.

We use a hand-collected and carefully compiled dataset. This helps us to avoid representation and survivorship biases which are often cited in relation to the price and company data on emerging equity markets. Our results confirm some of the existing evidence for developed markets, while challenge some of the other. We find that small stocks outperform large stocks and value stocks outperform growth stocks. The small value stocks show highest return while large growth stocks show the lowest return in the Polish stock market. We find evidence that the market factor, size, and book-to-market value factors all have explanatory power for the Polish stock returns. However, these three factors fail to fully capture the entire equity premium. The extension of the model by the liquidity factor, while reducing the occurrence of the statistically significant risk-adjusted excess returns, also fails to explain them fully. We therefore conclude that liquidity risk is less relevant for the Polish stock market. We leave the question about the other factors which may improve the explanatory power of the three-factor model for further research. 
Table 1: Descriptive statistics of the liquidity measures

\begin{tabular}{|c|c|c|c|c|c|c|c|c|c|c|}
\hline Statistics & LIQ_Zero & LIQ_Zero2 & LIQ_Amh & LIQ_AmhSqr & LIQ_AmhLog & LIQ_AmhMA & LIQ_Les & LIQ_Roll & Roll2 & LIQ_Liu \\
\hline mean & 0.1994 & 0.1407 & 62.5184 & 0.0012 & -0.2571 & 0.8742 & 7.0473 & 0.0253 & 0.0158 & 7.5124 \\
\hline median & 0.1500 & 0.1111 & 0.5955 & 0.0005 & -0.5184 & 0.0679 & 6.8162 & 0.0199 & 0.0100 & 0.0011 \\
\hline sd & 0.1887 & 0.1156 & 588.0475 & 0.0025 & 2.9726 & 3.9492 & 1.8464 & 0.0218 & 0.0209 & 19.3382 \\
\hline kurtosis & 6.3519 & 6.0261 & 446.2927 & 125.6753 & 2.9862 & 218.6692 & 4.9653 & 54.1524 & 20.7438 & 13.8344 \\
\hline $\min$ & 0.0000 & 0.0000 & 0.0003 & 0.0000 & -8.2730 & 0.0000 & 1.1568 & 0.0000 & 0.0000 & 0.0000 \\
\hline $\max$ & 1.0000 & 1.00001 & 17073.0200 & 0.0537 & 9.7453 & 89.2722 & 20.5248 & 0.6759 & 0.4230 & 138.9193 \\
\hline
\end{tabular}

Correlations

\begin{tabular}{|c|c|c|c|c|c|c|c|c|c|c|}
\hline LIQ_Zero & 1 & & & & & & & & & \\
\hline LIQ_Zero2 & 0.7243 & 1 & & & & & & & & \\
\hline LIQ_Amh & 0.1662 & 0.0656 & 1 & & & & & & & \\
\hline LIQ_AmhSrt & 0.3286 & 0.1437 & 0.7749 & 1 & & & & & & \\
\hline LIQ_AmhLog & 0.4408 & 0.2005 & 0.2843 & 0.6373 & 1 & & & & & \\
\hline LIQ_AmhMA & 0.1673 & 0.063 & 0.5923 & 0.5955 & 0.3703 & 1 & & & & \\
\hline LIQ_Les & 0.4381 & 0.2075 & 0.0496 & 0.2564 & 0.4106 & 0.0819 & 1 & & & \\
\hline LIQ_Roll & -0.0189 & -0.1299 & 0.1706 & 0.2865 & 0.2628 & 0.1925 & -0.1049 & 1 & & \\
\hline LIQ_Roll2 & 0.0976 & 0.0008 & 0.1691 & 0.3148 & 0.316 & 0.1902 & 0.1076 & 0.6191 & 1 & \\
\hline LIQ_Liu & 0.5451 & -0.0032 & 0.2024 & 0.3493 & 0.4576 & 0.2074 & 0.3465 & 0.1823 & 0.1677 & 1 \\
\hline
\end{tabular}

Notes: The table reports descriptive statistics and correlation coefficients for the liquidity measures. The sample period is 1996:1-2009:3 
Table 2: Summary statistics and correlation for risk factors

Panel A: Descriptive Statistics

\begin{tabular}{lrrrrr}
\hline & Mean & St. dev. & Skewness & Kurtosis & t-test \\
\hline MKT & -0.0055 & 0.0803 & -0.7651 & 5.4538 & -11.8902 \\
SMB & 0.0106 & 0.0675 & 1.0170 & 5.4942 & 25.0834 \\
HML & 0.0124 & 0.0536 & -0.8322 & 5.7739 & 37.1274 \\
IMV (LIQ_Zero) & -0.0004 & 0.0499 & -1.5612 & 11.2024 & -1.2123 \\
IMV (LIQ_Zero2) & 0.0028 & 0.0394 & 0.1417 & 3.8137 & 11.2206 \\
IMV (LIQ_Amh) & 0.0135 & 0.0658 & -3.1366 & 23.0219 & 32.8443 \\
IMV (LIQ_AmhSqr) & 0.0067 & 0.0537 & -1.2888 & 8.5110 & 19.9024 \\
IMV (LIQ_AmhLog) & 0.0041 & 0.0464 & -0.3549 & 4.6085 & 14.1678 \\
IMV (LIQ_AmhMA) & 0.0133 & 0.0676 & -2.9395 & 20.8268 & 31.5765 \\
IMV (LIQ_Les) & -0.0023 & 0.0548 & -2.4423 & 18.0225 & -6.6123 \\
IMV (LIQ_Roll) & 0.0025 & 0.0612 & -1.2549 & 6.6910 & 6.5485 \\
IMV (LIQ_Roll2) & 0.0004 & 0.0456 & -0.2790 & 4.7277 & 1.3398 \\
IMV (LIQ_Liu) & 0.0022 & 0.0526 & -1.4857 & 10.7317 & 6.7049
\end{tabular}

Panel B: Correlation Coefficients

\begin{tabular}{lrrrr}
\hline & MKT & SMB & HML & IMV (.) \\
\hline MKT & 1.0000 & & & \\
SMB & -0.0812 & 1.0000 & & \\
HML & -0.2815 & -0.1036 & 1.0000 & \\
IMV (LIQ_Zero) & 0.4728 & -0.1486 & 0.0303 & 1.0000 \\
IMV (LIQ_Zero2) & 0.4720 & 0.2018 & -0.1962 & 1.0000 \\
IMV (LIQ_Amh) & 0.3657 & -0.3145 & 0.2316 & 1.0000 \\
IMV (LIQ_AmhSqr) & 0.4639 & -0.3516 & 0.0599 & 1.0000 \\
IMV (LIQ_AmhLog) & 0.4521 & -0.3049 & -0.0351 & 1.0000 \\
IMV (LIQ_AmhMA) & 0.3000 & -0.3154 & 0.2452 & 1.0000 \\
IMV (LIQ_Les) & 0.3585 & -0.1760 & 0.1087 & 1.0000 \\
IMV (LIQ_Roll) & -0.2305 & -0.5806 & 0.1305 & 1.0000 \\
IMV (LIQ_Roll2) & 0.2307 & -0.4260 & 0.0958 & 1.0000 \\
IMV (LIQ_Liu) & 0.3415 & -0.0815 & 0.1056 & 1.0000 \\
\hline Notes: The tabl rep0rts & & &
\end{tabular}

Notes: The table reports descriptive statistics and correlations for the market, size, book-to-market and liquidity factors, indicated with MKT, SMB, HML and IMV (.). For each liquidity measure an individual liquidity factor is generated. "t-test" refers to the results of the t-test for the hypothesis that the mean is equal to zero. 
Table 3: Mean and standard deviation of excess returns of six Fama-French portfolios

\begin{tabular}{|c|c|c|c|c|}
\hline \multirow[t]{2}{*}{ Size category } & \multicolumn{3}{|c|}{ Book-to-market category } & \multirow[t]{2}{*}{ t-test } \\
\hline & $\mathrm{L}$ & M & $\mathrm{H}$ & \\
\hline S & $\begin{array}{c}0.006 \\
(0.114)\end{array}$ & $\begin{array}{c}0.006 \\
(0.099)\end{array}$ & $\begin{array}{c}0.020 \\
(0.095)\end{array}$ & -5.659 \\
\hline B & $\begin{array}{r}-0.008 \\
(0.086)\end{array}$ & $\begin{array}{c}0.003 \\
(0.080)\end{array}$ & $\begin{array}{c}0.005 \\
(0.075)\end{array}$ & -7.012 \\
\hline$\overline{\mathrm{t}}-\bar{t}_{\mathrm{test}}{ }^{-}$ & $5.284^{-}$ & & 7.820 & \\
\hline
\end{tabular}

Notes: The table is based upon monthly average excess returns on six size and book-to-market portfolios for the Polish stock market. Standard errors are reported in parantheses. The table is organized as follows: SL contains the monthly average excess return of the portfolio containing the stocks with the lowest market capitalization (S) and the lowest book-tomarket ratio $(\mathrm{L})$. The row and column labled "t-test" indicate the t-test-statistics for the differences-in-mean test between the values in the portfolios of the corresponding row and column. The sample period is 1996:1-2009:3. 
Table 4: Comparison of estimation results across size and book-to-market portfolios and different risk specifications

CAPM Fama-French

\begin{tabular}{|c|c|c|c|c|c|c|c|}
\hline \multirow[t]{2}{*}{ Coeff. } & \multirow{2}{*}{$\begin{array}{l}\text { Size } \\
\text { Categ. }\end{array}$} & \multicolumn{3}{|c|}{ Book-to-market equity category } & \multicolumn{3}{|c|}{ Book-to-market equity category } \\
\hline & & $\mathrm{L}$ & $\mathrm{M}$ & $\mathrm{H}$ & $\mathrm{L}$ & $\mathrm{M}$ & $\mathrm{H}$ \\
\hline \multirow[t]{2}{*}{$\alpha_{j}$} & S & $0.0097^{* * *}$ & $0.0101^{* * *}$ & $0.0237^{* * *}$ & $0.0044^{* * *}$ & $-0.0023^{* * *}$ & $0.0051^{* * *}$ \\
\hline & $\mathrm{B}$ & $-0.0015^{* * *}$ & $0.0061^{* * *}$ & $0.0091^{* * *}$ & $0.0011^{* * *}$ & $0.0053^{* * *}$ & $0.0020^{* *}$ \\
\hline \multirow[t]{2}{*}{$\beta_{j m}$} & S & $0.8242^{* * *}$ & $0.7548^{* * *}$ & $0.8474^{* * *}$ & $0.7718^{* * *}$ & $0.9296^{* * *}$ & $1.013^{* * *}$ \\
\hline & $\mathrm{B}$ & $1.0302^{* * *}$ & $0.9404^{* * *}$ & $0.6506^{* * *}$ & $0.9892^{* * *}$ & $0.9622^{* * *}$ & $0.7833^{* * *}$ \\
\hline \multirow{2}{*}{$\beta_{j s m b}$} & S & & & & $1.0168^{* * *}$ & $0.9850^{* * *}$ & $0.8742^{* * *}$ \\
\hline & $\mathrm{B}$ & & & & $-0.0884^{* * *}$ & $-0.0826^{* * *}$ & $0.0813^{* * *}$ \\
\hline \multirow[t]{2}{*}{$\beta_{j h m l}$} & $\mathrm{~S}$ & & & & $-0.5623^{* * *}$ & $0.4168^{* * *}$ & $0.6963^{* * *}$ \\
\hline & $\mathrm{B}$ & & & & $-0.1729^{* * *}$ & $0.1393^{* * *}$ & $0.6357^{* * *}$ \\
\hline
\end{tabular}

Notes: The table reports estimation results for the standard CAPM and the FamaFrench model, while stocks are sorted into six size and book-to-market portfolios. The table is organized as follows: SL contains the estimated coefficients based on the portfolio containing the stocks with the smallest market capitalization $(\mathrm{S})$ and the lowest book-to-market ratio $(\mathrm{L})$. The heading of the table indicates the underlying model. The models are estimated using Newey-West standard errors with six lags. $* * *, * *$ and $*$ indicates statistical significance of the coefficient at the $1 \%, 5 \%$ and $10 \%$ level, respectively. The sample period is 1996:1-2009:3. 
Table 5: Comparison of alphas across alternative risk specifications and across alternative liquidity measures

\begin{tabular}{|c|c|c|c|c|c|c|c|c|c|c|}
\hline$j$ & LIQ_Zero & LIQ_Zero2 & LIQ_Amh & LIQ_AmhSqr & LIQ_AmhLog & LIQ_AmhMA & LIQ_Les & LIQ_Roll & Roll2 & LIQ_Liu \\
\hline \multicolumn{11}{|c|}{ Panel A: CAPM } \\
\hline P1 & -0.0015 & -0.0023 & 0.0020 & 0.0018 & 0.0020 & 0.0020 & $-0.0097^{*}$ & 0.0018 & -0.0003 & -0.0026 \\
\hline P2 & $0.0102^{* * *}$ & $0.0105^{* * *}$ & 0.0047 & 0.0042 & 0.0047 & 0.0047 & 0.0005 & 0.0024 & 0.0018 & -0.0022 \\
\hline P3 & -0.0035 & -0.0017 & 0.0008 & 0.0034 & 0.0008 & 0.0008 & 0.0050 & 0.0034 & 0.0018 & 0.0023 \\
\hline P4 & -0.0001 & -0.0059 & 0.0001 & 0.0062 & 0.0001 & 0.0001 & 0.0001 & -0.0046 & -0.0017 & 0.0059 \\
\hline P5 & -0.0008 & -0.0024 & 0.0034 & -0.0021 & 0.0034 & 0.0034 & 0.0026 & 0.0075 & -0.0005 & 0.0030 \\
\hline$\overline{\mathrm{DiM}}^{-}$ & $-0.14 \overline{7} 6$ & $0 . \overline{0} 2 \overline{4} \overline{3}$ & $-\overline{0} 30 \overline{0} \overline{-}$ & $0.7 \overline{9} \overline{9}$ & $-\overline{0} . \overline{3} 07 \overline{9}$ & $-0.30 \overline{7} 9$ & $-2.1644^{* *}$ & $-\overline{0} \overline{9} \overline{6} 86$ & $0 . \overline{0} 4 \overline{4}$ & $-0 . \overline{8} \overline{19} \overline{7}$ \\
\hline GRS & $2.5462^{* *}$ & $2.9163^{* *}$ & 1.0937 & 1.3454 & 1.0937 & 1.0937 & 1.5933 & 1.4307 & 0.2103 & 0.8011 \\
\hline \multicolumn{11}{|c|}{ Panel B: Fama-French Model } \\
\hline P1 & 0.0014 & -0.0012 & $0.0035^{* * *}$ & $0.0033^{* * *}$ & $0.0035^{* * *}$ & $0.0035^{* * *}$ & -0.0074 & 0.0002 & 0.0001 & -0.0071 \\
\hline P2 & $0.0089^{*}$ & $0.0115^{* * *}$ & -0.0018 & -0.0026 & -0.0018 & -0.0018 & 0.0026 & 0.0037 & 0.0037 & -0.0017 \\
\hline P3 & -0.0059 & -0.0023 & $-0.0071^{* *}$ & -0.0042 & $-0.0071^{* *}$ & $-0.0071^{* *}$ & $0.0086^{* *}$ & 0.0015 & 0.0026 & 0.0009 \\
\hline $\mathrm{P} 4$ & $-0.0077^{*}$ & $-0.01^{* *}$ & $-0.0087^{* *}$ & -0.0023 & $-0.0088^{* *}$ & $-0.0088^{* *}$ & -0.0014 & -0.0027 & -0.0041 & 0.0053 \\
\hline $\mathrm{P} 5$ & -0.0044 & -0.0064 & 0.0004 & -0.0061 & -0.0004 & -0.0004 & -0.0007 & 0.0040 & -0.0025 & 0.0011 \\
\hline$\overline{\mathrm{DiM}}^{-}$ & $0.84 \overline{9} 2$ & $\overline{1} . \overline{0} 1 \overline{7} \overline{4}$ & $\overline{1} . \overline{3} \overline{59} 9^{-}$ & $2.12 \overline{8} 5^{* *}$ & $\overline{1} . \overline{3} \overline{7} \overline{9}$ & $1.3 \overline{7} \overline{5} 9$ & $-1.5 \overline{4} \overline{2} 2$ & $-\overline{0} . \overline{1} \overline{3} 1 \overline{3}$ & $0 . \overline{4} 8 \overline{4} \overline{5}$ & $-1 . \overline{1} 10 \overline{6}$ \\
\hline GRS & $2.2291^{*}$ & $4.6860^{* * *}$ & $3.4431^{* * *}$ & $2.0461^{*}$ & $3.4431^{* * *}$ & $3.4431^{* * *}$ & $3.3539^{* * *}$ & 0.7419 & 0.8528 & 0.9518 \\
\hline \multicolumn{11}{|c|}{ Panel C: Liquidity-augmented CAPM } \\
\hline P1 & -0.0010 & $-0.0036^{*}$ & 0.0006 & 0.0002 & 0.0002 & 0.0007 & -0.0037 & 0.0016 & -0.0005 & -0.0030 \\
\hline $\mathrm{P} 2$ & $0.0087^{* *}$ & $0.0106^{* * *}$ & 0.0039 & 0.0036 & 0.0047 & 0.0041 & 0.0012 & 0.0026 & 0.0024 & -0.0025 \\
\hline P3 & -0.0041 & -0.0019 & 0.0019 & 0.0067 & 0.0020 & 0.0021 & $0.0071^{* *}$ & 0.0030 & 0.0025 & 0.0022 \\
\hline $\mathrm{P} 4$ & -0.0013 & -0.0069 & 0.0016 & 0.0087 & 0.0027 & 0.0009 & -0.0004 & -0.0037 & -0.0040 & 0.0060 \\
\hline $\mathrm{P} 5$ & -0.0011 & -0.0027 & 0.0082 & 0.0042 & $0.0086^{*}$ & 0.0076 & 0.0006 & 0.0090 & -0.0011 & 0.0045 \\
\hline$\overline{\mathrm{DiM}}^{-}$ & $0.0 \overline{1} 28$ & -0.0603 & $-\overline{1} . \overline{19} 83$ & $-0.98 \overline{3} 2$ & $-\overline{1} . \overline{2} 6 \overline{5} \overline{5}^{-}$ & -1.0554 & -1.0086 & $-\overline{1} . \overline{1} 85 \overline{5}$ & $-\overline{0} . \overline{0} \overline{3} \overline{0}$ & $-1 . \overline{10} \overline{1} \overline{7}$ \\
\hline GRS & $1.9535^{*}$ & $3.3889^{* * *}$ & 1.2417 & 1.1642 & 1.3904 & 1.2413 & 1.8152 & 1.5563 & 0.6428 & 1.0826 \\
\hline
\end{tabular}

Continued on next page 
Panel D: Fama-French Model + Illiquidity Factor

\begin{tabular}{|c|c|c|c|c|c|c|c|c|c|c|}
\hline P1 & 0.0014 & -0.0019 & $0.0033^{* *}$ & $0.00312^{* *}$ & $0.0030^{* *}$ & $0.0035^{* *}$ & -0.00711 & 0.0000 & 0.0000 & -0.0072 \\
\hline $\mathrm{P} 2$ & $0.0089^{*}$ & $0.0111^{* * *}$ & -0.0020 & -0.0030 & -0.0016 & -0.0018 & 0.0029 & 0.0040 & 0.0056 & -0.0019 \\
\hline P3 & -0.0059 & -0.0017 & $-0.0067^{* *}$ & -0.0032 & $-0.0068^{* *}$ & $-0.0065^{* *}$ & $0.0083^{* *}$ & 0.0008 & 0.0026 & 0.0008 \\
\hline $\mathrm{P} 4$ & $-0.0078^{*}$ & $-0.0104^{* *}$ & $-0.0069^{*}$ & 0.0002 & -0.0049 & $-0.0076^{*}$ & -0.0014 & -0.0018 & -0.0041 & 0.0053 \\
\hline $\mathrm{P} 5$ & -0.0045 & 0.0062 & 0.0018 & -0.0018 & 0.0020 & 0.0012 & -0.0011 & 0.0047 & -0.0025 & 0.0017 \\
\hline$\overline{\mathrm{DiM}}$ & $0.99 \overline{2} 1$ & $0 . \overline{8} 8 \overline{8} \overline{5}$ & $\overline{0.6} \overline{6} \overline{6} 6^{-}$ & 0.8803 & $\overline{0} \overline{7} \overline{3} 4 \overline{2}$ & $0.84 \overline{4} 3$ & -1.3051 & $-\overline{0} \overline{3} \overline{5} \overline{73}$ & $0 . \overline{3} 9 \overline{9} \overline{6}$ & -1.2612 \\
\hline GRS & $2.3154^{* *}$ & $4.4487^{* * *}$ & $2.8257^{* *}$ & 1.4268 & $2.4285^{* *}$ & $2.9931^{* *}$ & $3.2818^{* * *}$ & 0.7407 & 1.1720 & 1.0133 \\
\hline
\end{tabular}

Notes: The table reports the estimation results for the intercepts, i.e. the average risk adjusted returns, of four asset-pricing models: the standard CAPM (Panel A), the Fama-French Model (Panel B), the liquidity augmented CAPM (Panel C) and the liquidity augmented Fama-French model (Panel D). The models are estimated for five different liquidity-portfolios each. P1 indicates the portfolio with the lowest illiquidity, P5 indicates the portfolio with the highest illquidity. The models are estimated using Newey-West standard errors with six lags. $* * *$, ** and $*$ indicates statistical significance of the coefficient and the test-statistics respectively, at the 1\%, $5 \%$ and $10 \%$ level, respectively. In addition, the table reports the values of the difference-in-mean test statistic (DiM), the GRS-test statistic (GRS) and the corresponding significances. 


\section{References}

Acharya, V. V. and L. H. Pedersen (2005). Asset pricing with liquidity risk. Journal of Financial Economics 77, 375-410.

Amihud, Y. (2002). Illiquidity and stock returns: Cross-section and time-series effects. Journal of Financial Markets 5, 31-56.

Amihud, Y. and H. Mendelson (1986). Asset pricing and the bid-ask spread. Journal of Financial Economics 17, 223-249.

Amihud, Y., H. Mendelson, and B. Lauterbach (1997). Market microstructure and securities values: Evidence from the Tel Aviv stock exchange. Journal of Financial Economics 45, $365-390$.

Atkins, A. B. and E. A. Dyl (1997). Transaction costs and holding periods for common stocks. Journal of Finance 52, 309-325.

Banz, R. W. (1981). The relationship between return and market value of common stocks. Journal of Financial Economics 9, 1-18.

Barry, C. B., E. Goldreyer, L. Lockwood, and M. Rodriguez (2002). Robustness of size and value effects in emerging equity markets, 1985-2000. Emerging Markets Review 3, 1-30.

Basu, S. (1977). The investment performance on common stocks in relation to their price to earnings ratio: A test of the efficient market hypothesis. Journal of Finance 50, 663-682.

Bauer, R., M. Cosemans, and P. C. Schotman (2008). Conditional asset pricing and stock market anomalies in Europe. European Financial Management.

Bekaert, G., C. R. Harvey, and C. Lundblad (2007). Liquidity and expected returns: Lessons from emerging markets. The Review of Financial Studies 20(4), 1783-1831.

Brennan, M. J., T. Chordia, and A. Subrahmanyam (1998). Alternative factor specifications, security characteristics, and the cross-section of expected stock returns. Journal of Financial Economics 49, 345-373.

Brennan, M. J. and A. Subrahmanyam (1996). Market microstructure and asset pricing: On the compensation for illiquidity in stock returns. Journal of Financial Economics 41, 441-464. 
Chalmers, J. M. R. and G. B. Kadlec (1998). An empirical examination of the amortized spread. Journal of Financial Economics 48, 159-188.

Chan, H. and R. Faff (2005). Asset pricing and the illiquidity premium. The Financial Review 40, 429-458.

Chordia, T., R. Roll, and A. Subrahmanyam (2000). Commonality in liquidity. Journal of Financial Economics 56, 3-28.

Chordia, T., R. Roll, and A. Subrahmanyam (2001). Market liquidity and trading activity. Journal of Finance 55, 501-530.

Chordia, T., R. Roll, and A. Subrahmanyam (2002). Order imbalance, liquidity, and market returns. Journal of Financial Economics 65, 111-130.

Claessens, S. and S. Dasgupta (1995). The cross-section of stock returns: Evidence from the emerging markets. World Band Policy Research Working Paper 1505.

Constantinides, G. M. (1986). Capital market equilibrium with transaction costs. The Journal of Political Economy 94, 842-862.

Cooper, S. K., J. C. Groth, and E. W. Avera (1985). Liquidity, exchange listing and common stock performance. Journal of Financial Markets 1, 203-219.

Datar, V. T., Y. N. Naranyan, and R. Radcliffe (1998). Liquidity and stock returns: An alternative test. Journal of Financial Markets 1, 203-219.

Eleswarapu, V. R. and M. R. Reinganum (1993). The seasonal behavior of the liquidity premium in asset pricing. Journal of Financial Economics 34, 373-386.

Fama, E. F. and K. R. French (1992). The cross-section of expected stock-returns. Journal of Finance 47, 427-465.

Fama, E. F. and K. R. French (1993). Common risk factors in the returns on stocks and bonds. Journal of Financial Economics 33, 3-56.

Fama, E. F. and K. R. French (1998). Value versus growth: The international evidence. The Journal of Finance 53, 1975-1999. 
Ferson, W. and C. Harvey (1999). Conditioning variables and the cross section of stock returns. Journal of Finance 54, 1325-1360.

Garleanu, N. (2009). Portfolio choice and pricing in illiquid markets. Journal of Economic Theory $144,532-564$.

Gibbons, M., S. A. Ross, and J. Shanken (1989). A test of the efficiency of a given portfolio. Econometrica 57, 1121-1152.

Glosten, L. R. and P. R. Milgrom (1985). Bid, ask, and transaction prices in a specialist market with heterogeneous informed traders. Journal of Finanical Economics 41, 401-439.

Griffin, J. M. (2002). Are the fama and French Factors global or country specific? The Review of Financial Studies 15, 783-803.

Haugen, R. A. and N. L. Baker (1996). Commonality in the determinants of expected stock returns. Journal of Financial Economics 41, 401-439.

Hu, A.-Y. (1997). Trading turnover and expected stock returns: The trading frequency hypothesis and evidence from the tokyo stock exchange. Manuscript.

Hyde, S. and S. Sherif (2009). Tests of the conditional asset pricing model: Further evidence from the cross-section of stock returns. International Journal of Finance $\&$ Economics.

Jacoby, G., D. Fowler, and A. A. Gottesman (2000). The capital asset pricing model and the liquidity effect: A theoretical approach. Journal of Financial Markets 3, 69-81.

Jagadeesh, N. and S. Titman (1993). Returns to buying winners and selling loosers implications for stock market efficiency. Journal of Finance 48, 65-91.

Jones, C. M. (2002). A century of stock market liquidity and trading costs. SSRN eLibrary.

Kamara, A., X. Lou, and R. Sadka (2008). The divergence of liquidity commonlaity in the cross-section of stocks. Journal of Financial Economics 89, 444-466.

Keim (1983). Size-related anomalies and stock return seasonality. Journal of Financial Economics 12, 13-32.

Khan and N. Baker (1993). Unlisted trading privileges, liquidity, and stock returns. The Journal of Financial Research 41, 221-236. 
Kyle, A. S. (1985). Continuous auctions and insider trading. Econometrica 53(6), 1315-1336.

Lesmond, D. A. (2005). Liquidity-augmented capital asset pricing model. Journal of Financial Economics 77, 411-452.

Lesmond, D. A., J. P. Ogden, and C. A. Trzcinka (1999). A new estimate of transaction costs. The Review of Finanical Studies 12(5), 1113-1141.

Liew, J. and M. Vassalou (2000). Can book-to-market, size and momentum be risk factors that predict economic growth? Journal of Financial Economics 57, 221-245.

Liu, W. (2006). A liquidity-augmented capital asset pricing model. Journal of Financial Economics 82, 631-671.

Llewellen, J. (1999). The time-series relations among expected return, risk and book-tomarket. Journal of Financial Economics 54, 5-43.

Marcelo, J. L. M. and M. del Mar Miralles Quiros (2006). The role of an illiquidity risk factor in asset pricing: Empirical evidence from the spanish stock market. The Quarterly Review of Economics and Finance 46, 254-267.

Pastor, L. and R. F. Stambaugh (2003). Liquidity risk and expected stock returns. Journal of Political Economy 111, 642-685.

Reingaum, M. R. (1981). Misspecification of capital asset pricing: Empirical anomalies based on earning yield and market values. Journal of Financial Economics 9, 19-46.

Roll, R. (1984). A simple implicit measure of the effective bid-ask spread in an efficient market. The Journal of Finance 39, 1127-1139.

Rouwenhorst, G. (1999). Local factors and turnover in emerging markets. Journal of Finance 54, 1439-1464.

Sadka, R. (2006). Momentum and post-earnings-announcements drift anomalies: The role of liquidity risk. Journal of Financial Economics 80, 309-349.

Schrimpf, A., M. Schröder, and R. Stehle (2007). Cross-sectional tests of conditional asset pricing models: Evidence from the German stock market. European Financial Management 13, 880-907. 
Subrahmanyam, A. (2009). The cross-section of expected stock returns: What have we learned from the past twenty-five years of research? Working Paper, UCLA.

van der Hart, J., E. Slagter, and D. van Dijk (2003). Stock selection strategies in emerging markets. Journal of Empirical Finance 10, 105-132.

Wang, F. and Y. Xu (2004). What determines Chinese stock returns. Financial Analysts Journal 60, 65-77. 